\title{
Banjar Traditional Food: Between Religion, Treatment, Daily Menu and Habits
}

\author{
Rissari Yayuk ${ }^{1}$, Jahdiah $^{2}$, Siti Alfa Ariestya ${ }^{3}$ \\ \{yrissariyayuk@yahoo.co.id ${ }^{1}$, Diah.banjar@yahoo.co.id², akualfa2010@yahoo.com³ ${ }^{3}$, \\ Balai Bahasa Kalimantan Selatan, Loktabat, Banjarbaru, Kalimantan Selatan
}

\begin{abstract}
The problems in this research are what are traditional Banjar Food used in the context of religion, of ethnomedicine, and of daily menu as a habit. The aims of this research are to describe traditional Banjar food used in the context of religion, of ethnomedicine, and of daily menu as a habit. The method used in this research is descriptive qualitative. Data collection techniques were carried out through observation, literature, interview, note-taking, and recordings. This research applies several steps, they are data collecting, sorting, analyzing, and presenting. This research uses anthropolinguistic theory. Data collection was carried out in Astambul, Pasayangan, and Cempaka from January to March 2021. The results show that Banjar traditional foods used in religious contexts are ketan, in ethnomedicine contexts are hintalu karuang, of daily menu are gangan waluh. The conclusion is a cultural social function for religion, medicine, and for daily meals.
\end{abstract}

Keywords: Traditional; Religion; Ethnomedicine

\section{Introduction}

Language is a reliable medium of communication. Language shows the identity of the speaker. Language is a tool to connect speakers in everyday social life. In fact, through language, the culture of people will be known.Duranti states that language is a precious thing in communication [1]. The translation summary of Udayana University Linguistics (S-1) and (S-2) students towards in Duranti says that language is a product of the interaction of social actors, they are the speakers themselves [2]. Meanwhile, in relation to language, Sirait states that language is part of culture. Culture can be learned through language [3]. Chaer states That language denotes culture [4]. Chaer states that through one's language he/she will know the origin of the people, social meaning, and the teachings of life that he adheres to [5]. Hastianah states that community culture can be expressed through daily traditions [6]. Ibrahim, et al states that language is a cultural resource that has a series of knowledge, beliefs, and values about speakers and their natural environment [7] .

One of regional languages in Indonesia that is still spoken today is Banjar language. It becomes the main language in South Kalimantan Province. Yulianto states that in daily life Banjar people have various names and forms of traditional foods, such as cakes, rice, fish, vegetables, and others. Traditional food of Banjar people have several functions, they are in ceremonies, treatment, and daily menus. These three functions become the identity of Banjar 
people in their daily life and become part of a social culture that has a tradition or habit. To find out the social meaning behind the names related to Banjar food, systematic research is needed.[8] Duranti in Muhidin states that broader meaning behind regional language will be known if the culture of the speaker is examined [9]. Duranti states that language is a cultural practice that has function as a means of expression [1].

Kurniasih states that human knowledge towards the management of present life will affect future environmental life [10].In the modern era which is instantaneous, knowledge that derived from scientific research on culinary or traditional food science is very important. Besides, adding the insight of regional cultural treasures, through this research, the basic ingredients of food which usually come from the natural environment will be revealed. Educationally it provides knowledge about the values of local wisdom related to culinary, as well as documenting the names, ingredients, and uses of that food which will later on affect the management of individual, social, and environmental lives in the future.

Based on this reason, researchers are very interested in discussing the problem of traditional Banjar food based on the aspects of religion, medicine, and their daily menu. To the researchers knowledge, there are few research about Banjar culinary based on these three aspects. The problems in the research are 1) what are traditional Banjar foods used in the context of religion as a habit, 2) what are traditional Banjar foods used in the ethnomedicine context as a habit, and 3) what are traditional Banjar foods used in the context of daily menu as a habit. The purpose of the study is to describe traditional Banjar food used in the context of religion as a habit, traditional Banjar food used in ethnomedicine contexts as a habit, and traditional Banjar food used in the context of daily menus as a habit. A previous study that examined food was conducted by Sari, et al entitled Gastronomi dalam Cerita Rakyat Ainu Jepang [11]. Sari, et al. concluded that gastronomy in Japanese folklore has forms and narratives related to how to obtain food, cook, and present the educational messages to the readers to respect the parents who obtain and cook the food [11].

The next research was carried out by Harsana, et al entitled Potensi Makanan Tradisional Kue Kolombeng sebagai Daya Tarik Wisata di Daerah Istimewa Yogyakarta. The results showed that Kolombeng had a tourist attraction because this cake is scarce, made from local ingredient, authentic, and has various shapes and names [12]. Based on that explanation above, there is a difference between the reserach conducted by the current research team and the two previous researches. Sari, et al the source of data are about food in Japanese folklore [11]. Meanwhile, the source data of Harsana, et al are about Traditional Food of the Kolombeng Cake. Both researches did not discuss food as a source of treatment. The similarities with current research are that both research discussing about food or culinary as part of the speakers culture [12].

\section{Literature Review}

Septiana states that culinary is related to food. Banjar traditional food is a part of culinary that has various names, forms of presentation, and functions that play an important role in people's daily activities [13]. Endraswara says that daily food in human life is not only a source of food but also a symbol of identity [14]. Sari states that through traditional food, the perspective and culture of the people will be revealed [15]. It confirms the opinion of Endraswara which states that there is a link between culture and supporting community. [16]

Based on that explanation, it can be said that one of social identities of Banjar people that can be revealed through language is food or culinary. This food or culinary cannot be 
separated in daily life, although it also depends on the situation and conditions that are adapted to its function. Food has function to fulfill the body's needs as an intake. It also has function as complement of belief in ceremonies, and as treatment. Andriyani states that food is a cultural concept when it viewed from anthropology point of view. Food has biological, social, cultural, and religious functions [17]. Endraswara states that food becomes a healthy source if it consumed properly. Food also has a function as health consumption [14].

Thus, traditional food or culinary is cooked and served not only to fulfill the body's or biological needs. The fulfillment of these biological needs is related to the consumption of food every day. In addition, foods have other functions, they are offerings for ceremonies or religions and sources of alternative medicine. Baihaqie states that culture is the result of human ingenuity [18]. This type of food that is cooked and served in Banjar community has regional characteristic. It is adapted to the needs and culture of the local community in their daily life. This daily activity cannot be separated from food and it becomes part of a routine culture that happened not by accidentally.

There is a process that requires energy, knowledge, and time until it formed habit or cultured habit. A habit is formed from human mind and its environment. People's habits in using food becomes a daily culture have a purpose, such as in order to face the demands of life both individually, socially, and their environment. Spradley states that culture is part of the knowledge system that humans acquire through the learning process in order to interpret the environment as well as to face the challenges around it [19]. Kamarulzaman and Barry state that habit is behavior obtained from lessons to react when it faced certain situation or stimulus; habit [20].

Traditional Banjar food is part of the Banjarese culture Seman states this traditional food is a cultural heritage object that has local wisdom value [21]. Ratna states that local cultural heritage has the value of wise local knowledge so it will support global knowledge for the sustainable of life. Wahyu states that local wisdom includes traditions and practices that have been going on for a long time and developed in certain areas, originally comes from a place or local communities in the form of policies, knowledge, and learning [22]. Sedyawati states that local wisdom is wisdom in traditional culture which includes health issues, material objects, knowledge, cultural values, technology, etc [23]. Putra states that the results of culture in the form of material objects are part of a set of symbols in human life that have functional or empowering benefits [24]. Tylor in Jufrizal says that culture is all knowledge, beliefs, and abilities of humans as members of society [25].

Related to this opinion, traditional food is one of regional folklore material in which it has a good social meaning. It is because behind the shape and name of the food there is skill to cook and serve the food. Both of them require knowledge from individuals and society. Endraswara states that material folklore implies the existence of thoughts, ideas, and skills in it. Language that describes culture can be seen in the meaning of the language lexicon, which is usually unique [26]. Asyura states that the peculiarity of a vocabulary or more that has a distinctive meaning becomes a mirror for the development of a particular culture [27].

\section{Methodology}

This study uses qualitative descriptive method. Creswall states qualitative methods based on interpretive non-numeric data [28]. Ratna states qualitative method utilizes the way of interpretation in the form of a description [29]. It is because the research team describes qualitatively about traditional food as part of the culture of Banjar people. Data collection 
techniques were carried out through observation, literature, interviewing, note-taking, and recording. The steps of data collection are carried out by sorting, analyzing data, and presenting. This research uses anthropolinguistics theory. Data collection was taken in Astambul, Pasayangan, and Cempaka from January to March 2021. This study uses several step, they are observation, data collection, editing, data analysis, and conclusions. Data analysis was carried out based on classifying the food for ceremonies or religion as a habit, food for treatment as a habit, and food for daily menu as a habit. The final conclusion generates a narration about traditional food of Banjar people that has become part of the routine activity in ceremonies, treatment, and daily menu.

\section{Results and Discussion}

\subsection{Traditional Banjar food is used in a Religious Context as a Habit}

Banjar traditional food which served in religious context is related to the use of this food in certain ceremonies. This section will describe the name of the food, its ingredients, and how to prepare it. The following are foods that categorized in the context of religion as a habit.

\section{a) Bubur habang 'red porridge' and bubur putih 'white porridge'}

Bubur habang 'red porridge' is one of culinary that is often served in every Banjar community ceremony. Bubur habang is a food made from rice and cooked to become porridge. The ingredients are 200 grams of rice, 100 grams of brown sugar, 1 cup of thick coconut milk, salt and sugar as desired. Before we cook porridge, we have to prepare all the ingredients. Wash the rice until clean then cook the rice until it becomes porridge, add salt and white sugar. Divide the porridge into two parts. One part is mixed with coconut milk and salt, the other part is mixed with brown sugar and granulated sugar. Cook the porridge again with brown sugar until everything is mixed. The porridge is served in the ceremony by putting red porridge and white porridge on a plate. Type of ceremonies that often use red porridge and white porridge are batampung tawar, traditional ceremony bakubuy 'the traditional ceremony of bathing for 7 months pregnant women', traditional ceremony of batumbang, batajak rumah 'build house ceremony'. Every time the ceremony is held, there is always red porridge and white porridge. It also served when someone's wish is granted.

\section{b) Wadai cincin}

Wadai cincin 'ring cake' is one of cakes that always served in every Banjar traditional ceremony. Ring cake is a cake which the main ingredient is rice flour. The ingredients used to make ring cake are 250 grams of rice flour, three bananas, $1 / 4$ spoon of salt, 50 grams of sugar, 250 grams of brown sugar, a glass of water, and cooking oil as needed. The way to make ring cake is as follows, mix rice flour, sugar, salt, and mashed banana, mix them well by hand. Shave brown sugar and add water, then cook in a pan until it thickened, after that mix it into the rice flour dough, knead the dough until well blended. Let the dough rest for 6 hours. Take a handful of dough and round it, grease it with cooking oil. Flatten it on top of the leaf and make four holes from the handful of dough that has been rounded earlier. Prepare hot oil for frying using medium heat, fry the dough, remove and drain. 
The ceremonies that often use ring cakes are the batampung tawar, bakubuy, batajak rumah, batamat quran 'a ceremony after finish reciting quran'. In every Banjar traditional ceremony there is always wadai cincin. There are several different ways of serving traditional cakes. For batampung tawar, the cake is hung on the baby's swing. In batajak ceremony, wadai cincin is hung on the main pole. In bakubuy ceremony, the ring is served on a plate. In batamat quran ceremony, wadai cincin is hung on the umbrella used to finish reciting quran.

\section{c) Cingkaruk}

Cingkaruk is one of traditional Banjar cakes that often served at traditional ceremonies. The ingredients to make cingkaruk are as follows, $1 / 2 \mathrm{~kg}$ of glutinous rice, 1 grated coconut, $1 / 2$ $\mathrm{kg}$ of brown sugar and $1 / 2$ liter of water. The way to make cingkaruk is as follows, soak glutinous rice overnight, then wash and drain. Roast glutinous rice and grated coconut until the color getting brown. Puree the roasted glutinous rice and grated coconut. Boil brown sugar with water then add salt and vanilla powder. Pour the grated coconut and glutinous rice then stir it constantly until the dough is blended. Cook the dough and stir it continuously. After it well cooked, put the dough on the tray, then flatten and let it cool. Cut the cake into pieces as desired. Cingkaruk is usually served in batampung ceremony, bakubuy, batajak rumah, and maingsat house. In every ceremony cingkaruk is served on the plate.

\section{d) Cucur}

Cucur is one of cakes that often used in Banjar traditional ceremonies. Cucur in traditional ceremonies has a philosophy to make business run smoothly as what we hope. Cucur is a cake that owned by several regions in Indonesia, including South Kalimantan. Cucur has sweet taste with a slightly soft texture. The ingredients to make cucur are as follows, prepare 500 grams of rice flour, 200 grams of wheat flour, 200 grams of grated brown sugar, 6 tablespoons of granulated sugar, 2 pandanus leaves, and cooking oil as needed. The way to make cucur is as follows, mix brown sugar, white sugar, and sliced of pandanus leaves with water and boil it. Strain the cooking water and let it sit until it's lukewarm. Mix the rice flour, wheat flour and salt together. Add the melted brown sugar gradually. Let the dough rest for 40 minutes, prepare a pan with hot oil. After that, pour one ladle of the dough into the frying pan with hot oil. Fry it until it has fluffy structure. After that, prick the middle of fluffy structure with a stick then remove and drain it. Cucur is ready to be served.

Cucur is often served in batampung ceremony, batajak rumah, baby shower, and batumpang. Batampung Tawar is a ceremony of giving a name to a newly born baby. Cucur at batampung tawar ceremony is hung on a swing that has been prepared before. Batajak rumah is a ceremony that often held by Banjar people when they want to build a house. Cucur is served in Batajak rumah ceremony then people eat it together. A seven-month bath is a baby shower ceremony performed at a seven-month pregnant woman. Cucur is served at this ceremony by serving it on a plate when the pregnant woman has finished doing baby shower then she sits on a place that has been prepared. The guests and neighbors are praying led by the village midwife or woman community leader. Batumpang is a ceremony performed by Banjar people, especially in Banjar Regency. This ceremony is performed when someone will go on pilgrimage. Cucur is placed on the top of prepared wood. 


\section{e) Wajik}

Wajik is one of cakes that often served in Banjar traditional ceremonies. The ingredients that should be prepared are 1 liter of glutinous rice, 100 grams of sugar, 250 grams of brown sugar, 3 cups thick coconut milk, salt, banana leaves, and cooking oil for greasing as needed. The way to make wajik is as follows, glutinous rice is soaked in water for 1 hour, then steam it. Cook coconut milk, brown sugar, sugar, pandan leaves, and salt until they are boiled. Pour the glutinous rice that has been steamed half cooked into the coconut milk mixture. Keep stirring it until thickened and cooked. Place banana leaf on a baking pan, clean the surface of leave and grease it with cooking oil. Flatten the dough and pressing it so that the texture is solid. Wait until it cools down and wajik is ready to be served. Wajik is served in traditional ceremonies such as batamat quran, baby shower ceremony, and batampung. Batamat quran ceremony is a ceremony that is held after a child has successfully completed reciting 30 chapters of the quran. In this ceremony, besides serving wajik, people also serve nasi lamak, and hintalu bajarang.

\section{f) Apam}

Apam is one of traditional cakes that exist in every area. It is always served in every traditional ceremony, including Banjar traditional ceremony. The ingredients to make apam are $150 \mathrm{gr}$ brown sugar, $150 \mathrm{ml}$ coconut water, 200 grams medium protein flour, $1 / 2$ teaspoon of instant yeast, $200 \mathrm{ml}$ coconut milk, $1 / 2$ tablespoon of salt, and 1 tablespoon of baking powder. The way to make apam 'apem' is as follows, boil brown sugar, coconut water, and pandanus leaves and stir it until dissolved. After that remove it and let it cool. Pour the mix solution gradually into the rice flour then knead it until soft. After it is cool, add the flour, instant yeast, coconut milk, and salt and mix on low speed for 15 minutes. Let the dough rest for 30 minutes then add baking powder, and mix until smooth. Pour the dough into the mold as desired, then steam for 30 minutes at high heat until it cooked. Apam is served in the batampun, batamat quran, baby shower, and batumpang ceremonies.

\section{g) Lakatan Bainti}

Lakatan Bainti is one of traditional Banjar cake that often served in Banjar traditional ceremonies. Lakatan Baiinti is commonly known as Nasi Balamak. The ingredients to make lakatan bainti are 1 liter of glutinous rice, 3 cups thick coconut milk, young coconut to make inti, brown sugar, and salt as needed. The way to make lakatan bainti is as follows, wash the glutinous rice then drain it, after that steam it until half cooked. Mix thick coconut milk and half cooked glutinous rice, stir it until smooth then steam again until cooked. After the dough is well cooked, remove it and put in the mold then pressing it until the sticky rice blends together. The ingredients to make inti are from grated coconut and brown sugar. Mix coconut, brown sugar, and salt, then stir them until well mixed. The way to serve lakatan baiinti is as follows, cut the cooked sticky rice from the mold then sprinkle inti made of grated coconut and brown sugar on top. Traditional ceremonies that often use lakatan bainti are batampung, batamat quran, batajak rumah, batatak hias, and batumbang. 


\subsection{Traditional Food Used for Medicine in Banjar People}

This section will describe the name of the food, its ingredients, and how to prepare it. The following are foods that categorized in traditional food used for medicine in Banjar people.

\section{a) Hintalu Karuang}

Hintalu karuang porridge is one of the traditional foods made from glutinous rice. The ingredients used to make hintalu karuang porridge are 200 grams of rice flour, 300 grams of glutinous rice flour, one spoon of whiting water, 250 grams of brown sugar, 800 grams of thick coconut milk, 1 sheet of pandanus leaves, and salt as needed. The way to make hintalu karuang porridge is as follows, mix rice flour, glutinous rice flour, salt, and warm water as needed gradually and knead it until smooth. Shape the dough into balls like the size of a marble. To prevent the shaped dough from sticking together, sprinkle rice flour on the top of the shaped dough. Boil the brown sugar, pandanus leaves, and coconut milk and stir it until it boiled, then put the shaped dough into the boiling water and cook until it floats. This porridge is served to treat people who are possessed by eating it.

\section{b) Hintalu Bajarang}

Egg is one of food source. For some people, egg can be consumed as a side dish and an alternative treatment. Besides eggs, there is also one ingredient that must be prepared, that is a large piece of turmeric. The method is as follows, the egg is cleaned and boiled. After a half cooked, take the yolk out, mix it with the grated turmeric juice then drink it. That potion can be used as a remedy for ulcers or stomach acid. This potion can be consumed directly. Usually after drinking it regularly every day, stomach acid disease will heal.

\section{c) Pucuk Luntas}

Pucuk beluntas or luntas are now rarely found around the resident of Banjar people, but this plant becomes one of advantageous vegetables for some people that have good benefits. The main ingredient is a handful of pucuk beluntas, wash it then boil it until cooked. This vegetable can be consumed directly or served with rice and other side dishes. This green vegetable can be used as an alternative treatment. That is reducing body odor.

\section{d) Sugar Palm Fruit}

Sugar palm fruit is easy to find in traditional markets. This fruit is white and a bit hard if it cooks in a short time. Banjar people usually consume this fruit by adding it into drinks. In addition, sugar palm fruit can be used to treat joints that lack of calcium. The fruit that has been cleaned and boiled can be eaten directly. Do it regularly so that the illness is cured.

\section{e) Pucuk Kastela}

Papaya in the Banjar language is called kastela. This food can be categorized as food sources, its young leaves can be used as fresh vegetables, which is called lalapan. Lalapan from pucuk kastela can be found in food stalls. Besides as lalapan, some Banjar people 
consume this vegetable to lose their weight. Those who often consume pucuk kastela are believed to have an ideal body.

\section{f) Nasi Lakatan}

Glutinous rice is part of food that is often consumed by Banjar people in various forms of serving. Besides as a main food, this rice can be consumed as the main ingredient of a snack, and alternative medicine. The way to cook this food is as follows, wash 1 liter of rice then steam it. When it is cooked and warm, glutinous rice can be consumed twice a day for several weeks. The benefit of this rice is to control blood sugar levels.

\subsection{Traditional Banjar Food used in Context of Daily Menu as a Habit}

\section{a) Nasi Kuning}

Nasi Kuning 'yellow rice' is one of Banjar culinary which is served as daily menu of Banjar people. Yellow rice is made from rice cooked with coconut milk. The ingredients are as follows, rice as needed, it can be 1 liter or more, 1 coconut, 1 slice of turmeric and water as needed to cook the rice. Here are the steps to cook it, the rise is washed and drained. The clean turmeric is grated and mixed with a little water and then filtered. Grate the coconut then add water, and filter it. Put the pan on the stove, cook the coconut milk and add turmeric juice, one slice of lemongrass, pandanus leaves, and lime leaves. Put the rice, water, and salt as needed, then steam the rice until half done. After that move the rice into the other pan and cook it until well done. Yellow rice is usually served with eggs, chicken, or catfish cooked with red chilies. This rice is easy to find in restaurant or regular stalls in the morning. Yellow rice is main menu that is often consumed in stalls as breakfast for Banjar people in general. Yellow rise is served on a plate or wrapped it in banana leaves.

\section{b) Bubur Banjar}

Banjar chicken porridge is one of culinary made from rice. The ingredients to make this porridge are 1 liter of rice, 1 carrot, 1 potato, 10 onion and 6 garlics, 1 leek, 1/4 tablespoon of pepper and nutmeg powder, salt and sugar as needed. The way to cook this food is as follows, wash the rice and mash the spices. Put the frying pan on the stove and pour oil as needed. Sauté the spices then pour the chicken stock and let it boil. Add rice and stir it until half cooked. Add some slices of potato and carrot. Wait until the porridge is cooked and stir constantly so it doesn't burn. Chicken porridge is usually served with pindang eggs, shredded chicken, crackers, and sprinkling of fried onions. This porridge is very delicious when it consume directly after it cooked. Banjar chicken porridge is usually easy to find in roadside stalls. This food is one of morning menu for Banjar people besides yellow rice and lontong.

\section{c) Lontong}

Lontong is one of favorite menu for Banjar people in general. The ingredients to make lontong are banana leaves, $1 / 2$ liter of rice, 1 coconut, 8 onions and 4 garlics, 5 candlenuts, one piece of galangal, turmeric, lemongrass, $1 / 4$ kilo unripe jackfruit, and $1 / 2$ kilo chili sauce. The way to make this dish is as follows, wash and drain the rice. Two pieces of banana leaves are rolled lengthwise or formed into a triangular cone. Fill a quarter of the banana leaf roll with 
rice. Put a large pot to boil the wrapped rice for about two to three hours. Wait it until well cooked, then let it cool. Lontong is usually served with gravy made from unripe jackfruit. Saute the spices such as onions, galangal, candlenut, turmeric, and lemongrass then add them to the boiled jackfruit. Add coconut milk and wait until it boils.

Lontong is served with gravy jackfruit and eggs or catfish cooked with red sauce. The side dish can be cooked as follows, boiled eggs and fried catfish. Saute the red sauce made from dried chilies with oil as needed. Add salt, sugar, flavor, and brown sugar as needed into the pan. After it smells good, add water, eggs and fried catfish. Like yellow rice and chicken porridge, lontong is one of favorite foods for Banjar people. Lontong Kuah is easy to find in several food stalls around Banjar community. Each portion of lontong kuah usually consists of two lontongs with one egg or one piece of fish. On the top this food is poured with gravy jackfruit.

\section{d) Gangan waluh}

Gangan waluh is one of vegetable that often made by Banjar people in their daily life. The ingredients of gangan waluh are $1 / 4$ of yellow pumpkin, 2 bunches of immature pumpkin leaves, 10 long beans, 1 baby corn, $1 / 2$ coconut, 4 onions, 3 garlics, sugar and salt as needed. The steps to make it are as follows, peel yellow pumpkin and cut into pieces, clean the immature pumpkin leaves, cut the long beans and wash them all. Take the coconut milk from $1 / 2$ coconuts. Peel and chop the onion and garlic. Put a pan on the stove, put pumpkin, immature pumpkin leaves, coconut milk, and spices in it then cook them. Next, add coconut milk, sugar, flavors, salt as needed. Wait until it boils. This vegetable is served at lunch. This type of culinary is easy to find in Banjar family homes in general and in food stalls that specializes selling Banjar menu. The ingredients of gangan waluh are easily to get everywhere or in traditional markets.

\section{e) Gangan karuh}

Gangan karuh is one of Banjar traditional dishes which consumed in daily life. This vegetable consists of 1 bunch of marsh kale, 1 banana blossom, 2 taro sweet potatoes, 3 unripe banana, 2 betok fish, one bunch of putri malu laut leaves, two onions, one garlic, three candlenuts, $1 / 2$ teaspoon of tamarind, and $1 / 4$ teaspoon of shrimp paste. Here is how to make this food, clean taro then cut it and put it in a pan filled with water. Boil it until half cooked, after that through away the water. Bananas are also boiled in a half cooked, after that through away the water. Re-boil taro, banana, and betok fish with mashed spices. After it is cooked, put in putri malu laut leaves, salt and sugar as needed. Wait until it cooked. This culinary is often made in Banjar family. This vegetable is often sold in food stalls. Gangan karuh is usually consumed with hot rice and chili paste mixed with chopped fruit.

\section{f) Рариуи Baubar}

Pариуu baubar is a grilled fish. The ingredients of this food are 4-5 papuyu, salt, cooking oil, and 3 tablespoons of tamarind water. After the fish is cleaned, coat it with lime and let it rest for about 10 minutes. Wash the fish then soak it in tamarind water and give salt as needed. Next, grill the fish on medium hot coals. After the fish is well cooked, usually it served with lalapan or cacapan. Cacapan is a traditional Banjar pickle consisting of chopped unripe mango, chilies, and onion. Put this ingredient in lukewarm water then put the grilled fish in it. 


\section{g) Oseng Mandai}

Mandai is a popular traditional food in most Banjar people. The ingredients of this food are 1 piece of salted or unsalted cempedak skin, 5 onions and 3 garlics, 2 green and red chilies, 1 tomato, $1 / 2$ tablespoon of sugar, salt, and flavor. Here is how to make this food, clean cempedak skin and cut into cubes, then soaked it for a while in hot water. Saute the spices in a frying pan, then put in the cempedak skin then stir it until cooked. Oseng mandai is usually consumed with hot or warm rice. For mandai lovers, this food can increase their appetite. This dish is available in various restaurants or in a family menu.

Based on the results of the analysis, it can be seen that traditional Banjar food has three function, they are for ceremonies or religion, medicine, and daily menu. The names of these foods have similarities, and differences with the Indonesian language, likewise with the ingredients and the way they cooked. Meanwhile, when we see it from the origin of the ingredients, in general, these ingredients come from local environment, except ingredients that cannot or are rarely found in Banjar community, for example, flavor, salt, carrots, potatoes, etc. The type of traditional food served in ceremonies is generally in the form of cakes with the basic ingredients of wheat flour and rice flour. Rice flour is divided into rice flour and glutinous rice. Each ceremony can use the same or different types.

Next, for traditional foods that cooked for medicinal purposes are made from vegetables and animals, these ingredients come from local area. The way to cook it is simple with the same advantage like chemical drugs. Lastly, traditional food for daily menu of various types has basic ingredients from vegetables, fish, and rice. The origin of food ingredients can be obtained either from their own garden or traditional markets. Culture is an attitude and belief to think and act in a society [30]. This culture can be known through the local language about the variety of food with all forms and functions. This shows that humans through daily food are able to use it to meet physical and spiritual needs. Hendriyanto, et al. Stating that humans fulfill their needs in accordance with applicable rules [31]. The form, processing, and function of food in Banjar society is proof that food is not only for personal consumption. There are cultural values contained in it. Culture that shows the wisdom of the local community in interpreting the meaning of traditional food for individual and social life.

\section{Conclusion}

The results showed that traditional Banjar foods used in the context of religion as a habit are bubur habang, bubur putih, cucur, wadai cincin, cingkaruk, wajik, apam, and lakatan bainti. Traditional Banjar foods used in the context of ethnomedicine as a habit are hintalu karuang, hintalu bajarang, sugar palm fruit, pucuk luntas, pucuk kastela, nasi lakatan. Traditional Banjar foods used in the context of daily menu as a habit are nasi kuning, lontong, gangan waluh, gangan karuh, oseng mandai.

\section{Acknowledgment}

We would like to thank all those who have provided support in participating in this seminar. We would like to thank the seminar committee and the head of the Central Kalimantan Provincial Language Center who gave us the opportunity to participate. Likewise to the head of the South Kalimantan Provincial Language Center who allowed us to attend the 
seminar. All participants and colleagues who provide valuable input for the improvement of this paper.

\section{References}

[1] Duranti,A., Linguistic Anthropology. Inggris: Combridge, University Press, 1997.

[2] Duranti, A., Companion to linguistic Anthropology. Wiley Blackwell., 2004.

[3] Sibarani, Robert, Antropolinguistik. Medan: Moda, 2004.

[4] Chaer,A., Tata Bahasa Praktis Bahasa Indonesia. Jakarta: Rineka Cipta, 1985.

[5] Chaer,A., Sosiolinguistik: Perkenalan Awal. Bandung: Rineka Cipta, 2013.

[6] Hastianah, "Nuansa Sosiokultural dalam Ungkapan Ajektiva Majemuk Bahasa Makasar: Tinjauan Sosiolinguistik," Sawerigading, vol. 22, no. 2, pp. 401--413, 2016.

[7] Ibrahim, A.S., Dkk, Antropologi linguistik. Bandung: Refika, $201 \mathrm{AD}$.

[8] Yulianto, Agus , "Kearifan Lokal dalam Sastra Daerah Banjar Genre Puisi," Undas, vol. 1, no. 2, pp. 1-11, 2015.

[9] Rahmat, M.,"Nilai Pendidikan Karakter dalam Cerita Rakyat Kakak Beradik Tange dan Berei," J. Lingko, vol. 1, no. 2, pp. 162-175, 2019.

[10] Nurhidayati, Kurniasih,"Kearifan Lingkungan dalam Kumpulan Cerpen Pilangur Salusin Kisdap Banjar," Undas, vol. 16, no. 2, pp. 297-310, 2020.

[11] Sari. I. A. L., Dkk, "Gastronomi dalam Cerita Rakyat Ainu Jepang. Jurnal Seni Budaya,” J. Seni Budaya, vol. 30, p. 235-50, 2020.

[12] Harsana, Minta, Dkk., "Potensi Makanan Tradisional Kue Kolombeng sebagai Daya Tarik Wisata di Daerah Istimewa Yogyakarta," HEJ (Home Econ. Journal)., vol. 2, no. 2, p. $40-47,2018$.

[13] Septiana, D, "Penamaan Kuliner dalam Masyarakat Dayak Maanyan," Suar Betang, vol. 12 , no. 1 , pp. $15-25,17$ AD.

[14] Endraswara, S., Gastronomi Sastra. Yogyakarta: Textium, 2018.

[15] Sari, Y.P., "Sajian Kue Banjar 4 macam: Kajian Etnolinguistik," Undas, vol. 13, no. 2, pp. 117-128, 2017.

[16] Endraswara, S, Metodologi Penelitian Folklor. Yogyakarta: Media Pressindo, 2017.

[17] Andriyani, "Kajian Literatur pada Makanan dalam Perspektif Islam dan Kesehatan," $J$. Kedokteran dan Kesehatan., vol. 15, no. 2, pp. 178-198, 2019.

[18] Baihaqie, Imam, Enolinguistik. Surakarta: Cakrawala Media, 2013.

[19] James P. Spradley, J.P., Metode Etnografi. Yogyakarta: Tiara Wacana, 6AD.

[20] Kamarulzaman, AKA, Dkk., Kamus Ilmiah Serapan Bahasa Indonesia. Yogyakarta: Absolut, 2005.

[21] Seman,Samsiar, Wadai Banjar 41 macam. Banjarmasin: Lembaga Pendidikan Banua, 2013.

[22] Wahyu, Pendidikan IPS berbasis Kearifan Lokal. Bandung: Wahana Jaya, 2015.

[23] Sedyawati, E., Budaya Indonesia. Jakarta: PT Rajagrafindo Persada, 2012.

[24] Putra, H. S. A.,. (ed), Arkeologi dan Sumber Daya Budaya di Kalimantan. Banjarbaru: IAAI Komda, 2020.

[25] Jufrizal, Antropological Linguistics, an introduction for beginners. Yogyakarta: Graha Ilmu, 2018.

[26] Endraswara, S, Metodologi Penelitian Folklor. Yogyakarta: Media Presindo, 2008.

[27] Asyura, Muhammad., "Analisis Konten Lagu Melayu Tradisional dan Modern Pemaknaan Lirik-lirik Lagu Melayu Kalimantan Barat,” Tuah Talino, vol. 13, no. 2, 
pp. 66--77, 2018.

[28] Creswall, J.J., Research Desighn: Qualitative, Quantitative, and Mixed Methods Approaches, California. Sage Publication, 2003.

[29] Ratna, Nyoman Kutha, Teori, metode, dan Teknik Penelitian Sastra. Yogyakarta: Pustaka Pelajar, 2006.

[30] Yulianto, Agus, “Akulturasi Budaya dalam Cerpen Hitam Putih Kotaku Karya Rismiyana,” undas, vol. 16, no. 2, pp. 157-168, 2020, doi: https://doi.org/10.6499/und.v16i2.2764.

[31] Hendriyanto, Agoes, Dkk., "Filosofi Jawa dalam Seni Kethek Ogleng Desa Tokawi, Kecamatan Nawangan, Kabupaten Pacitan," Sirok Bastra, vol. 6, no. 1, pp. 105-115, 2018. 